\title{
China-US Trade Flow Behavior: The Implications of Alternative Exchange Rate Measures and Trade Classifications
}

\author{
Yin-Wong Cheung*, Menzie D. Chinn ${ }^{* *}$, Xingwang Qian ${ }^{\dagger}$
}

This version: February, 2015

\begin{abstract}
$\underline{\text { Abstract }}$
We examine Chinese-US trade flows over the 1994-2012 period, and find that, in line with the conventional wisdom, the value of China's exports to the US responds negatively to real renminbi (RMB) appreciation, while import responds positively. Further, the combined empirical price effects on exports and imports imply an increase in the real value of the RMB will reduce China's trade balance. The use of alternative exchange rate measures and data on different trade classifications yields additional insights. Firms more subject to market forces exhibit greater price sensitivity. The price elasticity is larger for ordinary exports than for processing exports. Finally, accounting for endogeneity and measurement error matters. Hence, the purging the real exchange rate of the portion responding to policy, or using the deviation of the real exchange rate from the equilibrium level yields a stronger measured effect than when using the unadjusted bilateral exchange rate.
\end{abstract}

Keywords: import, export, elasticity, real exchange rate, processing trade

JEL classification: F12, F41

Acknowledgments: We thank Willem Thorbecke, and participants of the 2014 CEANA/CEA session at ASSA, the $5^{\text {th }}$ annual G2 at GWU conference, and seminar participants at the Shanghai University of Finance and Econoimcs for their comments and suggestions. We also thank Rob Johnson and Robert Dekle for sharing data with us. Previous versions of the paper were circulated under the title "The structural behavior of China-US trade flows."

\section{Corresponding Addresses:}

* Hung Hing Ying Chair Professor of International Economics, Department of Economics and Finance, City University of Hong Kong, Hong Kong. Tel/Fax: (852) 3442-7312/0194. Email: yicheung@cityu.edu.hk

** Robert M. La Follette School of Public Affairs, and Department of Economics, University of Wisconsin, 1180 Observatory Drive, Madison, WI 53706-1393. Tel/Fax: (608) 262-7397/2033. Email: mchinn@lafollette.wisc.edu

$\dagger \quad$ Economics and Finance Department, SUNY Buffalo State, 1300 Elmwood Ave, Buffalo, NY 14222. Tel: (716) 878-6031. Email: qianx@buffalostate.edu. 


\section{Introduction}

In spite of the recent diminishment of China's current account surplus, from heights of $10.1 \%$ of its GDP in 2007 to $2.1 \%$ in 2013, the controversy surrounding China's exports and its exchange rate policy has not entirely disappeared. In the April 2014 Report to the Congress on International Economic and Exchange Rate Policies, the US Treasury maintained the view that the Chinese currency, the renminbi (RMB), remains significantly undervalued and the progress on rebalancing the global economy remains inadequate. Yet other scholars characterize China's exports to the US as an outlier (Thorbecke, 2014).

The challenges of dissecting China's trade behavior are well known; see, for example, Ahmed (2009), Aziz and Li (2008), Cheung, Chinn and Fujii (2010), Cheung, Chinn and Qian (2012), Kwack et al. (2007), Mann and Plück (2007), Marquez and Schindler (2007), and Thorbecke and Smith (2010). Many analysts have had tremendous difficulty in pinning down the responsiveness of Chinese trade flows to exchange rates and levels of economic activity. In some cases, the price elasticity estimate has the wrong sign. The absence of a consensus regarding the price elasticity certainly does not help settle the debate regarding the design of policies to eliminate global imbalances.

Formal statistical analyses have to deal with a few obstacles in analyzing Chinese trade. Some of these obstacles are the dynamism of the Chinese economy, the paucity of price deflators, and the unique Chinese policy measures. All these factors contribute to the findings of unconventional price elasticity estimates. Over time, researchers have realized the importance of incorporating the China-specific elements in studying China's exports and imports.

In the current study, we focus on the China-US trade and examine it from several different perspectives. In doing so, we hope our results will convey the complex nature of China's trade and provide plausible estimates useful for policy discussion. The major innovations in our study involve the analysis of disaggregated data, the use of alternative measures of the real exchange rate, and a more appropriate estimation method able to account for nonstationarity.

On the first point, in addition to aggregate trade, we examine disaggregated trade flows, classified along different dimensions. The main classifications are (i) processing and ordinary trade, (ii) manufactured and primary products, and (iii) trade activities of state owned enterprises, foreign invested enterprises, and private enterprises. 
On the second point, we rely upon alternative measures of the exchange rate in order to assess the price elasticity of trade flows. We conjecture that the difficulty in measuring the real $\mathrm{RMB}$ exchange rate effect on trade may be due to the inappropriate choice of the exchange rate variable. The use of different exchange rate variables could shed some light on the role of exchange rate variable. In our empirical exercise, we consider three real bilateral exchange rate variables; the first one is the commonly used consumer-price-index-based real exchange rate, the second one is derived from a two-step procedure to alleviate possible endogeneity, and the last one is the estimated deviation from the equilibrium rate ${ }^{1}$.

On the third point, the estimation technique, we adopt a procedure that allows the data to possess different levels of stationarity. It is notoriously difficult to determine the stationarity property of macroeconomic data. Dealing with this issue is critical for obtaining accurate inferences. We use the Pesaran, Shin and Smith (2001) framework that can accommodate the possibility that the data comprise both I(1) and I(0) series.

Finally, we augment the typical set of determinants with China-specific factors, in order to account for China's special circumstances.

To anticipate our findings, we find that, in line with the conventional wisdom, the value of China's exports to the US is adversely affected by the strength of its currency. The exchange rate effect on the Chinese imports from the US is also consistent with the general notion that imports increase with the RMB value, even though the evidence is slightly weaker than those from the exports data. Further, the combined empirical price effects on exports and imports imply an increase in the real value of the RMB will reduce China's trade balance.

The use of alternative exchange rate measures and data on different trade classifications yields additional insights. Firms more subject to market forces exhibit greater price sensitivity. The price elasticity is larger for ordinary exports than for processing exports,

Finally, accounting for endogeneity and measurement error matters. Hence, the purging the real exchange rate of the portion responding to policy, or using the deviation of the real exchange rate from the equilibrium level yields a stronger measured effect than when using the unadjusted bilateral exchange rate.

1 In addition, we tried three other measures for the RMB real exchange rate - the value added REER (Bems and Johnson, 2012), the REER incorporated Chinese Agriculture productivity (Deckle and Ungor, 2013), and the integrated REER (Thorbeck, 2013). The results are not reported in the paper, but available from authors upon request. 


\section{Background}

Figure 1 presents the evolution of China's overall trade balance, the China-US bilateral trade balance, and the Chinese-US bilateral real exchange rate. A few observations are in order. First, China's trade account was rough in balance before 2004. Second, China's trade surplus reached the high of 186 billion US\$ in 2007, a period that is coincided with the intense debate regarding the pace of RMB valuation. Since then China's trade balance has shrunken. Third, China's trade surplus against the US is, pattern-wise, similar to its overall surplus. Fourth, the real appreciation of the RMB does not appear to rein in China's trade surplus.

Figure 2 presents the China-US bilateral trade as a share of their aggregate trade statistics. When expressed as a share of China's total exports, China's exports to the US hover around the $20 \%$ mark - it is above 20\% between 1998 and 2007 and is below in other periods. The ratio of China's import from the US to China's total imports is declining during the sample period; it drifts gradually from above to below $10 \%$.

On the other hand, China's exports to the US account for an increasing share of the US total imports. That is, a larger proportion of imports into the US is coming from China. Similarly, the US exports to China (that is, China's imports from the US) relative to the US total exports is increasing over time. Nevertheless, the increase in China's exports to the US is faster than the US exports to China. Apparently, from China's point of view, the trade with the US is quite stable to declining a bit. For the US, the trade with China is gaining importance in its overall trade activity.

Figures 3, 4, and 5 show the pattern of China's exports to the US when disaggregating trade along three different classifications - processing and ordinary trade, manufactured and primary products, and trade activities of state owned enterprises, foreign invested enterprises, and private enterprises, respectively. Processing exports account for averagely about $2 / 3$ of total China's exports to the US during 2001-2012. ${ }^{2}$ Ordinary exports has gradually gained $10 \%$ more share since 2004 (Figure 3). Majority of China's exports to the US are manufactured products, booked for about $90 \%$ and increasing (Figure 4).

2 Processing exports are exports that comprise imported raw and intermediate components. These components are imported into China by authorized enterprises with preferential tax treatments and for producing products for exports. 
Echoing the privatization process in China, Chinese exports to the US handled by state owned enterprises and private enterprises displayed a quite contrasting path. State owned enterprises have consistently given up the ground to private enterprises which raised the total exports share from $4 \%$ in 2001 to about $30 \%$ in 2012 . Foreign investment enterprises remained to be the major exporter in China that export about $60 \%$ of total Chinese exports to the US in the last decade (Figure 5). ${ }^{3}$

\section{Exports: Empirical Results}

To begin, we first focus on China's exports to the US. Specifically, China's export behavior is assessed using the specification

$$
e x_{t}=\theta_{0}+\theta_{1} y_{t}^{*}+\theta_{2} r_{t}+\theta_{3} r_{t}^{*}+\theta_{4} z_{t}+u_{t},
$$

where $e x_{t}$ is China's real exports to the US. The canonical output and price effects are captured by the US real GDP variable $y_{t}^{*}$ and a measure of the real dollar-Renminbi exchange rate $r_{t}$. The so-called third-country price effect is assessed using the variable $r_{t}^{*}$, which is the real effective exchange rate of the US dollar against the ASEAN-5 economies; namely Indonesia, Malaysia, Philippines, Singapore, and Thailand. ${ }^{4}$ Processing imports are imported to facilitate the production of finished products in China for (re-)exporting. China's real processing imports variable $z_{t}$ is included to account for the fact that Chinese exports incorporate imported inputs, and many of those imported inputs are classified as processing imports. In line with standard practice, variables are entered in log terms. See Appendix A for sources and definitions of these variables and other data used in the empirical exercise.

\subsection{The Pesaran, Shin and Smith Procedure}

3 In this study, the once popular township and village enterprises, also known as collective or alliance enterprises are grouped under the heading of private enterprises. Strictly, the term "township and village enterprises" does not mean that these enterprises are owned by towns and villages. They are typically located in towns and villages, sponsored by townships and villages, and owned by private entities. Exports by these enterprises are quite small and declining over time.

$4 \quad$ Eichengreen et al. (2007), Gaulier et al. (2006) and Thorbecke (2006), for example, report evidence on China is competing with ASEAN economies in exports markets; especially in labor-intensive products. 
Estimation of the exports equation (1) is complicated by requirement in standard econometric procedures that the variables have the same order of integration. The unit root test results (reported in Appendix B) indicate that the variables under consideration evidence different orders of integration; some are I(1) and some are I(0) variables. In order to make appropriate inferences, we adopt a flexible procedure proposed by Pesaran, Shin and Smith (2001) that allows the variables to have different orders of integration.

In the current context, this procedure tests the dependence between exports and the other variables based on the following autoregressive distributed lag model of order $(p, q)$

$$
\Delta e x_{t}=\beta_{0}+\beta_{1} e x_{t-1}+\beta_{2} y_{t-1}^{*}+\beta_{3} r_{t-1}+\beta_{4} r_{t-1}^{*}+\beta_{5} z_{t-1}+\sum_{j=0}^{p} \varphi_{j}^{\prime} \Delta X_{t-j}+\sum_{j=1}^{q-1} \omega_{j} \Delta e x_{t-j}+\varepsilon_{t},
$$

where $X_{t} \equiv\left(y_{t}^{*}, r_{t}, r_{t}^{*}, z_{t}\right)$. Under the null hypothesis of $\beta_{1}=\beta_{2}=\beta_{3}=\beta_{4}=\beta_{5}=0$, there is no level relationship between the Chinese exports and the other variables in equation (2). This flexible dynamic specification does not restrict changes in the Chinese exports and other variables to have the same lag structure. ${ }^{5,6}$

Assuming that (1) represents the level relationship under which all the first differenced variables in equation (2) are jointly zero, we retrieve the estimates of $\theta$ 's using these equations: $\theta_{1}=-\beta_{2} / \beta_{1} ; \theta_{2}=-\beta_{3} / \beta_{1}, \theta_{3}=-\beta_{4} / \beta_{1}$, and $\theta_{4}=-\beta_{5} / \beta_{1} .{ }^{7}$ Usually, the level relationship is interpreted as a (conditional) empirical long-term relationship.

\subsection{Aggregate Data on Exports}

The sample period is from 1994Q1 to 2012Q4. Because of the paucity of the Chinese trade price indexes, we used the Hong Kong unit value index of re-exports to US to derive the

$5 \quad$ Pesaran, Shin and Smith (2001) derive critical value bounds based on two sets of distribution functions to cover cases in which the variables have different orders of integration. Thus, the price for the robustness is the possibility of an inconclusive inference if the test statistic falls within the bounds. The exact critical value can be derived with information about the stationarity of the explanatory variables.

6 In estimating the model, a vector of time dummy variables capturing effects of seasonal factors, 1997 financial crisis, China's WTO accession in 2001, the RMB exchange rate reform in 2005, and 2008 global financial crisis, as well as a time trend and its interaction terms with those time dummies are also included. For brevity, coefficient estimates of these dummy variables are not reported below.

7 The asymptotic distribution of $\theta$ can be derived using the delta lemma. 
Chinese data on real exports. ${ }^{8}$ Note that Hong Kong is the most important entrepot for China trade. For the current case, the null hypothesis of $\beta_{1}=\beta_{2}=\beta_{3}=\beta_{4}=\beta_{5}=0$ is rejected at the $1 \%$ level. That result indicates that there is evidence for the presence of long term relationship between Chinese exports and other variables. ${ }^{9}$. For brevity, except for the $F$ and $t$ statistics, other results of testing the no-relationship null hypothesis are not reported but available upon request. ${ }^{10}$

Table 1 presents the estimation results pertaining to equation (1). The results reported under columns (1) are based on the bilateral CPI-based RMB-US dollar real exchange rate - a higher rate implies a stronger RMB. The exchange rate garners a large and statistically significant negative coefficient estimate. That is, the Chinese exports are responsive to exchange rate changes as predicted by conventional trade theory.

The US income effect is quite large - a one percent increase in real income implies a three-percent increase in real exports (after allowing for a deterministic time trend). The thirdcountry exchange rate variable $r_{t}^{*}$ has the wrong sign ${ }^{11}$ - the larger the $r_{t}^{*}$, which implies a lower value of third-country exchange rates, the higher level of the Chinese exports to the US - but it is not statistically significant.

China's exports are characterized by processing exports, which involve the assembly of imported parts and components. Indeed, $60 \%$ to $70 \%$ of the Chinese exports to the US are processing exports. The significance of the processing imports variable $z_{t}$ illustrates the role of processing trade. A $1 \%$ increase in real processing imports is associated with about $0.44 \%$ increase in the Chinese exports to the US. In passing, we note that the real exchange rate effect will be strengthened to -2.5 (and significant at the 1\% level) from -1.7 when the processing imports variable is excluded.

8 The BLS reports a price index for Chinese imports into the United States, but the series only begins in 2004 . Hence, we do not calculate a volume series based on this deflator.

9 The lag parameters $p$ and $q$ are selected based on the Bayesian Information Criterion and the Jarque-Bera test.

10 The same null hypothesis was rejected in all the subsequent exports equation specifications. That is, there is empirical evidence of the presence of long term relationship between the selected Chinese exports series and the associated factors. These test results again are not reported to conserve space but are available upon request.

11 Given previous research (e.g. Eichengreen et al. 2007 and Thorbecke, 2006), our prior is that Chinese and ASEAN goods are substitutes in the US market. Thus, a depreciation of ASEAN real exchange rate makes ASEAN exports more competitive in the US market. 
While the CPI-deflated real exchange rate is a common measure of the strength of a currency, in the Chinese case, its use might yield misleading inferences. As indicated in Figure 1 and anecdotal evidence, China's trade surplus and the RMB value tend to move in tandem, contra the typical expectation. One possible reason for this positive association is that China's exchange rate policy responds to, among other things, its trade surplus. For instance, appreciation in the presence of a high level of trade surplus is politically feasible because the external pressure for appreciation is strong, and the adverse effect of the appreciation on the domestic economy is not imminent.

To control for this possible feedback effect, we adopt a two-stage approach to construct a RMB exchange rate variable. Essentially, we include the trade balance in a Taylor-rule type exchange rate equation with several Chinese specific variables. Then the estimated real bilateral exchange rate is used as the exchange variable $r_{t}$ in equation (1). The construction of this real bilateral exchange rate series is described in Appendix C. The estimated results based on the estimated exchange rate data are presented under Column (2) of Table 1.

The coefficient estimates under Columns (1) and (2) of Table 1 are quite similar; indicating that the estimating results based on the "two-stage" RMB exchange rate are qualitatively similar to those based the CPI deflated real exchange rate. Specifically, the third country exchange rate variable remains statistically insignificant, while the other three variables are statistically significant, and with the expected signs. Note that the price elasticity associated with the two-stage RMB exchange rate is just below 1; a one percent appreciate leads to a slightly less than $1 \%$ decline in exports. The impact of processing imports, on the other hand, is strengthened to 0.66 .

In the next analysis, we examine the impact of deviations from a longer term equilibrium exchange rate as the relevant measure. The rationale for such approach is straightforward. The CPI deflated real exchange rate tends to appreciate over time due to the Balassa-Samuelson effect, given that tradable sector productivity typically exceeds nontradable. Yet the relative price of tradable goods is what is relevant for trade flows. Hence, if one can extract the trend component arising from the Balassa-Samuelson effect, and focus on deviations from the trendor longer term equilibrium - exchange rate, one might obtain a more precise estimate of the sensitivity of trade flows to the relevant relative price. Another way of thinking about this 
approach is to think about the CPI-deflated real exchange rate as measuring with error the relevant real exchange rate.

In this context, a change in the level of over- or undervaluation would induce changes in trade activities. This perspective is consistent with the argument that the Chinese trade surplus is supported by a Chinese policy of maintaining an undervalued RMB. This observation further motivates the examination of the response of trade activity to an estimated degree of undervaluation.

Despite the general difficulty of determining the equilibrium level of an exchange rate, there is a plethora of studies on assessing the degree of the RMB undervaluation. ${ }^{12}$ In the current study, the deviation from the equilibrium exchange rate is evaluated using a Penn-effect-type regression:

$$
q_{t}=\alpha+\beta y_{t}+\varepsilon_{t},
$$

where $y_{t}$ is China's GDP relative to the US one, and the GDP data are PPP-adjusted output data normalized by the level of employment. The real RMB real exchange rate against the US dollar is denoted by $q_{t}$. Both $q_{t}$ and $y_{t}$ are in logarithm. The degree of misalignment under the relative productivity framework is given by $\varepsilon_{t}$; a negative $\varepsilon_{t}$ indicates undervaluation of the RMB.

The estimated exchange rate effect under Column (3) of Table 1 is stronger than those reported in the other two columns. If the observed exchange rate variation has two components, namely, the change in the equilibrium rate and the change in the level of misalignment, the result highlights the role of deviations from the equilibrium on trade. At the same time, the US output effect is also stronger while the other two determinants become insignificant. Apparently, our measure of deviations from the equilibrium exchange rate has a relatively strong influence on the exports activity.

In sum, regardless of which one of the three alternative exchange rate variables is considered, there a consistent price effect on the Chinese exports to the US. The evidence lends support to the view that the Chinese exports are responsive to its exchange rate, and the response to the deviation from the equilibrium rate is quite strong.

12 Studies using different exchange rate models and different methods of calculation, along with the issue of China data uncertainty, generate a wide dispersion of RMB misalignment estimates. A sample of these studies includes Cheung, Chinn and Fujii (2007, 2009, 2010b), Coudert and Couharde (2007), Frankel (2006), and Wang (2004). 


\subsection{Disaggregating Exports}

In the next three subsections, we investigate whether disaggregating the exports data yields insights into price and income elasticities. The disaggregation is implemented along several dimensions - ordinary vs. processing, ownership status of exporting firm, and primary vs. manufactured goods. Due to data availability, the sample period for the ordinary and processing exports data, and the exports data of state own enterprises (SOEs), foreign invested enterprises (FIEs), and private enterprises is from 2001Q1 to 2012Q4, while the sample period for the primary and manufactured goods exports are from 1994Q1 to 2012Q4.

\subsubsection{Ordinary and Processing Exports}

It is well known that China is the critical segment of a global production chain. It assembles a wide variety of products with imported inputs and exports the complete or almost complete final product to the rest of the world. As a result, processing exports that involve (re)exporting goods after processing and/or assembly within the country are a main Chinese trade activity. Despite a declining trend associated with this activity (Figure 3), the processing exports still account for close to $60 \%$ of the Chinese exports to the US. The prevalent of processing exports obscures the usual price effect because an RMB appreciation lowers the cost of imported intermediate goods, which in turn, mitigates the appreciation effect on the price of processing exports. ${ }^{13}$

Following the empirical procedure in Section 3.2, we study the effect of the exchange rate on these two types of exports, and present the results in Table 2. For all three exchange rate variables, the price effect is negative as expected and is statistically significant. Moreover, the implied price elasticity is usually larger than one. The price elasticities of the usual bilateral real exchange rate and the one derived from the two-stage procedure are larger for ordinary than processing exports; see Columns (1), (2), (4), and (5). The results are in line with the notion that a large imported component (or equivalently a small value added component) weakens the exchange rate effect on processing exports.

13 The importance of differentiating the ordinary and processing exports is emphasized in, for example, Ahmed (2009), Cheung, Chinn, and Qian (2012), Garcia-Herrero and Koivu (2007), and Marquez and Schindler (2007). 
The deviation from the equilibrium exchange rate, however, shows a different pattern, and displays a stronger impact on processing than ordinary exports (Columns (3) and (6)). The result corroborates the usual claim that Asian economies tend to follow China's RMB valuation to stay competitive in the global market. ${ }^{14}$ If these economies feed the production chain operation in China, the devaluation (appreciation) of their currencies will reinforce the effect of RMB devaluation (appreciation) on trade.

The significance of the other explanatory variables depends on the specification. For the three ordinary exports specifications, the output and third-country effects have the right signs and are significant for two of these three cases. On the other hand, both the output and third-country price variables are insignificant for processing exports. The results pertaining to $r_{t}^{*}$ highlight the possible competition between China and other Asian economies in the US market; the competition effect is significant for the ordinary exports, but it is quite weak for processing trade. We conjecture that this is true as these exports incorporate considerable imported components from overseas including other Asian countries.

Surprisingly, even though the estimates are all positive, the processing imports variable $z_{t}$ is only statistically significant in one of the three processing exports specifications - the one that uses the two-stage real exchange rate variable. The processing trade variable effect is, however, stronger than those reported in Table 1; a 1\% increase in real processing imports is associated with about $1.2 \%$ increase in the Chinese processing exports to the US.

Despite the heterogeneity in the results, one consistent finding is that, for either ordinary and processing exports, China's exports respond to prices in a significant fashion.

\subsubsection{Primary and Manufactured Goods Exports}

The astonishing economic growth enjoyed by China in the recent decades has been driven by a fast growing manufacturing sector that supports a rapidly expanding export sector. Figure 4 shows the share of manufactured goods exports accounts for the lion's share of China's exports to the US while the exports of primary products experienced a slight decline. It is generally believed that a large fraction of manufactured goods exports are processing exports. Some typical examples are iPhones and laptop computers.

$14 \quad$ See, for example Fratzscher and Mehl (2014), McKinnon and Schnabl (2003), Subramanian and Kessler (2013). 
Table 3 summarizes the results of examining the differing behavior of the Chinese exports of primary and manufactured products. Our dichotomy of primary and manufactured goods follows the convention of the Harmonized System code. Specifically, the "primary" group comprises products with codes ranging from 01 to 27 and the "manufacturing" group covers product codes from 28 to 97.

In five out of six cases, the real exchange rate effect is statistically significant with the expected negative sign. The insignificant case is given by the two-stage exchange rate variable under the primary product specification. Again, the evidence lends support to the usual view that exports performance is adversely affected by a strong currency.

The coefficient estimates of the US output variable are all positive, although it is significant in only four of the six cases. The significance of the third-country exchange rate variable varies between the two types of exports. While the third-country price variable is significant with the expected negative sign for the primary exports, it has wrongly signed, albeit insignificant, coefficient estimates for manufactured exports. The result is suggestive of the third country competition is more intense in China's exports of primary products than of manufactured goods. In the latter categories, the processing trade attribute may dampen the third country competition effect. Such an interpretation is corroborated by the significance of the processing imports variable in the exports equations of manufactured products.

\subsubsection{Exports and Firm Ownership}

China's reform policies have substantially altered the incentives facing economic actors. As a consequence, the prevalence of various types of corporate governance has shifted drastically. The dominance of state owned enterprises has been, and continues to be, eroded by the arrival of foreign invested enterprises and private enterprises. These different ownership structures imply, among other things, different organization structures, operational environments, and incentive schemes. Figure 5 attests to the general belief that the foreign invested enterprises and private firms in China are growing at the expense of state owned enterprises. The share of the exports by state owned enterprises to the US has declined in the $21^{\text {st }}$ century, while those of the other two types have grown. 
Do the exports of these different types of firms exhibit different behaviors? Table 4 reports the results of estimated the exports equations, broken down by state owned enterprises, foreign invested enterprises, and private enterprises.

The price effect estimates obtained from this classification scheme are largely in accordance with those from the other two classification schemes; that is, the Chinese exports respond to prices. The coefficient estimates of the three exchange rate variables are all negative. While those from the foreign invested and private enterprises are statistically significant, only the exchange rate derived from the two-stage procedure is significant for the case of state owned enterprises.

For each of the three exchange rate cases, the state owned enterprises display the weakest price effect while the private enterprises are the most sensitive to prices. The relative rankings of price effects are in line with the belief that prices are not necessarily the most important factor for the operation of state owned enterprises. Private enterprises in general have a strong profits incentive, and thus are quite sensitive to economic factors. Relative to private enterprises, the foreign invested enterprises could have a wide array of instruments to manage the impact of exchange rate variability, and thus, are less sensitive to exchange rates.

The performance of other explanatory variables varies across firm types. For instance, only the exports by state owned enterprises exhibit strong income effects. The processing imports variable shows up as significant in the cases of state owned and foreign owned enterprises, but not private enterprises. For private enterprises, the third-country price effect is statistically significant in two regressions, but with opposing signs. The drivers of differing results warrant further study.

In sum, the results from disaggregated data reinforce the findings from aggregate data. Chinese exports to the US are sensitive to the exchange rate movement. The price sensitivity is revealed, albeit with varying degrees of intensity, by three alternative measures of the bilateral real exchange rate. Furthermore, the variations in the price effects across different groups of exports categories are in general quite intuitive.

\section{Additional Analyses}

4.1 China's Imports 
We study China's imports from the US using the following imports equation and autoregressive distributed lag model

$$
i m_{t}=\gamma_{0}+\gamma_{1} y_{t}+\gamma_{2} r_{t}+\gamma_{3} r_{t}^{\sim}+\gamma_{4} w_{t}+u_{t},
$$

and

$$
\Delta i m_{t}=\beta_{0}+\beta_{1} i m_{t-1}+\beta_{2} y_{t-1}+\beta_{3} r_{t-1}+\beta_{4} r_{t-1}^{\sim}+\beta_{5} w_{t-1}+\sum_{j=0}^{p} \varphi_{j}^{\prime} \Delta Z_{t-j}+\sum_{j=1}^{q-1} \omega_{j} \Delta i m_{t-j}+\varepsilon_{t},
$$

where $y_{t}$ is China's real GDP, $r_{t}^{\sim}$ captures the "third" country exchange rate effect with the RMB real effective exchange rate against European Union currencies, $w_{t}$ is China's productivity in the manufacturing sector relative to the US, ${ }^{15}$ and $Z_{t} \equiv\left(y_{t}, r_{t}, r_{t}^{\sim}, w_{t}\right)$. As in the case of exports, the level relationship parameters $\gamma_{i}$ 's are inferred from the corresponding $\beta_{i}$ 's from (5). ${ }^{16}$

The results of estimating China's import behavior are summarized in Table 5. For brevity, the price effects on imports based on the bilateral exchange rate extracted from the two-stage procedure are presented. Those based on the other two exchange rate variables are available upon request. $^{17}$

The estimated price effects on the aggregate imports from the US and its sub-categories are all positive; that is, the stronger the Chinese currency, the larger volume of imports. Similar to the case of exports, the magnitude of price effect varies between different types of import activities. With the exceptions of imports of manufactured goods and imports by private enterprises, the price-elasticity estimates are statistically significant. The estimated exchange rate effect is quite encouraging as it suggests that the response of China's imports to the exchange rate is in accordance with the usual wisdom; a RMB appreciations lead to an increase in China's imports.

This finding is of interest because earlier studies have failed to detect a significant and correctly-signed price effect for Chinese imports, including Cheung et al. (2010a, 2012). We

15 For discussions on including relative productivity in China's imports equation, see, for example, Aziz and Li (2008), Cheung, Chinn and Qian (2012), and Chinn (2006).

$16 \quad$ For all the imports equations reported below, the null hypothesis of $\beta_{1}=\beta_{2}=\beta_{3}=\beta_{4}=\beta_{5}=0$ is rejected at the $1 \%$ level. That is, there is an empirical long term relationship between Chinese imports and other variables. The lag parameters $\mathrm{p}$ and $\mathrm{q}$ are selected based on the Bayesian Information Criterion and the Jarque-Bera test. For brevity, the results of testing the null hypothesis are not reported but available upon request.

17 The price effects based on the other two measures are, in general, qualitatively similar to those in Table 5. 
conjecture one reason is that accounting for the endogeneity of the exchange rate using the two stage procedure allows us to better measure the price elasticity of imports. An alternative explanation relies upon the observation that the majority of Chinese imports from US are ordinary goods (more than 90\%), which might mean that Chinese imports are more sensitive to price changes.

It is of interest to note that the price effect displayed by private enterprises is small and statistically insignificant -- a finding that is in sharp contrast with the export behavior of private enterprises.

The effects of other explanatory variables are less conclusive. The income effect is significantly positive as stipulated for only the case of private enterprises; it is insignificant in the other seven cases. The third country exchange rate effect is significant with the expected negative sign for only the categories of ordinary and processing imports. Disaggregation thus seems to yield limited insights in this regard. The relative productivity variable, when it is statistically significant, is negative with the exception of data of private enterprises. The negative effect is in accordance with the notion that a high level of China's competitiveness reduces its demand for imports.

In sum, empirically, Chinese import behavior reported in Table 5 is largely in line with the textbook prescription - a higher value of the RMB is associated with a higher level of imports. Nevertheless, we note that, relatively speaking, China's imports from the US are more difficult to model than its exports to the US.

\subsection{The Marshall Lerner Condition}

The Chinese trade surplus has been a subject of contention between China and the rest of the world. Exchange rate adjustment is a natural policy prescription to address the excessive trade surplus. Specifically, the Marshall Lerner condition shows that, starting from a point of trade balance and perfectly elastic supply, an exchange rate appreciation reduces the size of trade balance when the sum of the price elasticities of exports and imports is larger than one.

The elasticity estimates presented above allow us to gauge the exchange rate effect on China's trade account, at least starting from the counterfactual of balanced trade. The second and third columns of Table 6 present the exports and imports price elasticity estimates derived from the bilateral exchange rate extracted from the two-stage procedure. The test statistics of the 
hypothesis of the sum of two price elasticities is unity. For the aggregate trade between China and the US, the Marshall Lerner condition is met; that is, RMB appreciation will shrink China's trade balance with the US. The other results depend on the way the trade data are classified.

The Marshall Lerner condition is met for the two components under the processing and ordinary trade classification. That is, when the RMB appreciates, it will dampen China's total processing trade and total ordinary trade surpluses. Interestingly the relative exchange rate effect differs across these two types of trade data. The price elasticity estimates show that the exchange rate effect is stronger for ordinary exports than ordinary imports, and is stronger for processing imports than processing exports.

The results from the other two forms of trade classification are not the clear cut. When we look at trade on primary goods and manufactured products, the sum of the two price elasticity is not significantly larger 1, and thus the Marshall Lerner condition is not satisfied. Indeed, the sum is less than 1 for trade in primary goods.

For trade activity conducted by SOEs, even though the numerical value of the MarshallLerner condition is met, the sum of the two price elasticity estimates is not statistically larger than 1. That is, there is no statistical evidence that an RMB appreciation will reduce the trade balance of China's SOEs. For the FIEs and private enterprises, the Chi-square test shows that the Marshall-Lerner condition is met. For these two types of enterprises, the overall effect on trade balance is dominated by the negative price effect on exports.

Taking these results together, we are inclined to believe the Marshall-Lerner condition holds for the bilateral aggregate China-US trade. For specific trade sub-categories, RMB appreciation may not reduce the trade balance, even when starting from balance. That's a natural consequence of different export and import sub-categories displaying different price elasticities. One implication is that exchange rate policy has differential effects on categories of the trade balance.

\section{Concluding remarks}

We study the bilateral trade, both imports and exports, between China and the US with a focus on the exchange rate effect. In view of the diverse results reported in the literature, we adopt an estimation procedure that is valid under alternative assumptions regarding the degree of integration of the data, alternative exchange rate measures (including accounting for endogeneity 
and measurement error), and alternative means of disaggregating the data. In addition, we include factors that are relevant to China's recent unique experiences.

Our preliminary data analyses confirmed that the variables under consideration exhibit different degrees of integration. That finding motivates the use of the Pesaran, Shin and Smith procedure, which mitigates the possibility of spurious results. In general, we find that, in line with the conventional wisdom, the value of China's exports to the US is adversely affected by the strength of its currency. The exchange rate effect on the Chinese imports from the US is also consistent with the general notion that imports increase with the RMB value, even though the evidence is slightly weaker than those from the exports data. Further, the combined empirical price effects on exports and imports imply that an increase in the real value of the RMB will reduce China's trade balance.

The use of alternative exchange rate measures and data on different trade classifications yields additional insights. One not altogether surprising result is that the estimated exchange rate effect varies across exchange rate measures and trade classifications. The encouraging aspect is that the pattern of variation is largely in line with intuition: firms more subject to market forces exhibit greater price sensitivity. Thus, the exchange rate effect is stronger for exports by private enterprises than by state owned enterprises. When the value added is larger, the sensitivity to price changes is larger; hence, the elasticity is larger for ordinary exports than for processing exports,

Finally, accounting for endogeneity and measurement error matters. Hence, the instrumented (two-stage) exchange rate and the deviation from the equilibrium level display a stronger effect than the unadjusted bilateral exchange rate. 


\section{Appendix A: Definitions of Variables}

Dependent variables: China's exports to, imports from the US in aggregate, trade type (ordinary and processing trade), products type (primary and manufactured products), and firm type (SOE, FIE, and Private firms) data. Nominal exports data are deflated by the Hong Kong unit value index of re-exports to US; and nominal imports are deflated by the Hong Kong unit value index of re-exports to China.

GDP US:

GDP_CN:

RER:

The US real GDP in the 2005 price, in logarithmic form.

China's real GDP in the 1995 price, in RMB and logarithmic form.

The bilateral real exchange rate between RMB and USD, calculated as the nominal exchange rate deflated by both CPIs of China and the US, in logarithmic form. A large RER indicates a high RMB value.

REER_US/ASEAN: The real effective exchange rate of USD against ASEAN-5, in logarithmic form. A large REER_US/ASEAN means a high USD value.

REER_CN/EU: The real effective exchange rate of the RMB against the Europe Union currencies, in logarithmic form. A large REER CNY/EU means a high RMB value.

Proc_Imports: China's total procession imports deflated by the Hong Kong unit value index of re-exports to China, in logarithmic form.

Prod: $\quad$ China's relative productivity, measured by the Chinese GDP per employment in the secondary industry relative to the US manufacture output per job.

Afc97: $\quad$ A time dummy variable of the Asian financial crisis (= 1 if $\mathrm{t}>=1998 \mathrm{Q} 1$; $=$ 0 , otherwise)

WTO: $\quad$ A time dummy variable of China's accession to WTO at Dec, 2001 (= 1 if $\mathrm{t}>=2002 \mathrm{Q} 1 ;=0$, otherwise).

Reform: $\quad$ A time dummy variable of China's exchange rate reform in July 2005 ((= 1 if $\mathrm{t}>=2005 \mathrm{Q} 3 ;=0$, otherwise)

Gfc08a: A time dummy variable of the global financial crisis in 2008 ( $=1$ if $\mathrm{t}>=2008 \mathrm{Q} 4 ;=0$, otherwise).

Gfc08b: $\quad$ A time dummy variable of the plummet time periods of the global financial crisis in 2008 ( $=1$ if $\mathrm{t}>=2008 \mathrm{Q} 4,2009 \mathrm{Q} 1,2009 \mathrm{Q} 2 ;=0$, otherwise).

SED: $\quad$ A time dummy variable of the Strategic and Economic Dialogue between China and US.

Q1,Q2,Q3 The quarterly dummy variables

Trend: $\quad$ A time trend variable. 


\begin{tabular}{|c|c|c|c|c|}
\hline & \multicolumn{2}{|c|}{ DF-GLS with a trend } & \multicolumn{2}{|c|}{$\begin{array}{l}\text { ADF test with one structural } \\
\text { break in both mean and trend }\end{array}$} \\
\hline & tau-statistics & lags & $t$-statistics & break point \\
\hline Aggregated exports & -1.127 & 5 & -2.950 & $2001 \mathrm{q} 4$ \\
\hline Primary goods exports & -1.610 & 8 & -3.037 & $2001 \mathrm{q} 4$ \\
\hline Manufactured goods exports & -1.770 & 4 & -2.880 & $2001 \mathrm{q} 4$ \\
\hline Ordinary exports & -0.753 & 5 & -2.596 & $2003 q 4$ \\
\hline Processing exports & -1.442 & 4 & -2.848 & $2002 \mathrm{q} 4$ \\
\hline SOE exports & -1.561 & 4 & $-3.915^{*}$ & $2008 \mathrm{q} 2$ \\
\hline FIE exports & -0.986 & 5 & $-4.083 *$ & $2001 \mathrm{q} 4$ \\
\hline Private firms exports & -1.046 & 4 & -2.583 & $2001 q 4$ \\
\hline Aggregated imports & $-2.836^{*}$ & 4 & -1.978 & $2002 q 1$ \\
\hline Primary goods imports & $-3.251 * *$ & 4 & -2.197 & $2002 q 3$ \\
\hline Manufactured goods imports & -1.783 & 8 & -1.648 & $2002 q 1$ \\
\hline Ordinary imports & $-4.552 * * *$ & 1 & -1.451 & $2006 \mathrm{q} 3$ \\
\hline Processing imports & -2.188 & 1 & $-4.295 * *$ & $2011 \mathrm{q} 3$ \\
\hline SOE imports & $-6.009 * * *$ & 1 & -0.291 & $2004 q 4$ \\
\hline FIE imports & -1.236 & 1 & -3.029 & $2001 \mathrm{q} 4$ \\
\hline Private firms imports & -1.155 & 2 & -2.382 & $2002 q 1$ \\
\hline China's real GDP & -1.715 & 4 & -0.935 & $2004 q 2$ \\
\hline US real GDP & -0.997 & 2 & -3.089 & $1995 q 4$ \\
\hline RMB-USD real exchange rate & -2.740 & 8 & -3.787 & $2007 q 1$ \\
\hline $\begin{array}{l}\text { USD-ASEAN real effective } \\
\text { exchange rate (REER) }\end{array}$ & -1.371 & 1 & -2.530 & $1997 q 1$ \\
\hline RMB-Euro REER & -1.518 & 1 & -2.362 & $2001 \mathrm{q} 4$ \\
\hline China's total processing imports & -1.044 & 5 & -2.936 & $2001 \mathrm{q} 4$ \\
\hline $\begin{array}{l}\text { The change of China-US relative } \\
\text { productivity }\end{array}$ & -1.162 & 3 & $-3.740 *$ & $2008 \mathrm{q} 3$ \\
\hline Output gap & -1.319 & 10 & -0.656 & $2011 \mathrm{q} 1$ \\
\hline China's inflation & -1.228 & 5 & $-4.140 *$ & $2007 q 2$ \\
\hline China's deposit rate & -0.479 & 1 & $-6.039 * * *$ & $1995 \mathrm{q} 4$ \\
\hline China's trade surplus & -2.198 & 4 & -3.169 & $2003 q 4$ \\
\hline
\end{tabular}

Note: All exports data are deflated by the Hong Kong re-export to US unit value index and all imports data are deflated by the Hong Kong re-export to China unit value index, in logarithm. The finite sample critical value at $5 \%$ significant level for DF-GLS test and ADF test with one structural break are from Cheung and Lai (1995) and Perron and Vogelsang (1992), respectively. The lag structure is decided by SBIC. The break points are endogenously identified from a grid search method. 


\section{Appendix C: the Two-stage process}

The RMB exchange rate effect on Chinese exports to the US allowing for possible feedback of China's trade surplus to the RMB exchange rate is studied as follows.

The feedback effect of trade surplus to RMB exchange rate is accounted for in the following equation in the $1^{\text {st }}$ stage,

$$
r_{t}=\alpha+\gamma_{1} Z_{t}+\gamma_{2} X_{t}+\varepsilon_{t}
$$

where $r_{t}$ is the RMB real exchange rate; $Z_{t}$ is a vector of variables that $r_{t}$ responds to, including China's total trade balance ${ }^{18}$ and three Taylor rule factors - China's output gap, inflation rate, and interest rate differential (Chinn, 2008). Other variables in equation (1) in the text are included in $X_{t}$ as the exogenous variables to meet the necessary condition for identification in a two-equation system (See Baltagi, 2002, Chapter 11 for details). A Bounds test for (C1) is performed in an ARDL setting with a time trend and time dummy variables including 1997 and 2008 financial crises, 2005 exchange rate reform, SED, and their interaction terms with time trend, been included. The fitted value for $r_{t}$, notated as $\widehat{r}_{t}$, is generated from the long-run level relation.

In the second stage, we run a Bounds test as specified in equation (2) and estimate the long-term level relation with $r_{t}$ in equation (1) replaced by $\widehat{r}_{t}$.

This two-step process might entail the issue of generated regressors, in that $\widehat{r}_{t}$ is an estimated variable. In essence, we use an estimated proxy to measure the actual variable. In doing so, we are measuring it with an error. Thus, regressions using generated regressors yield biased standard errors that can lead to improper inferences. In our exercise, the inferences are based on the corrected variance-covariance matrix estimate and the associated standard errors recommended by Baltagi (2002) and Pagan (1984).

18 There might be a concern that China's export to the US contained in China's total trade balance in the first stage regression (C1) explains itself in the second stage regression. While it is possible in theory, the data show the correlation between China's overall exports/imports and China-US bilateral exports/imports are relatively low, about $14.9 \%$ and $5.5 \%$, respectively. Moreover, China's overall trade balance only explains a small fraction of real exchange variability. 


\section{References}

Ahmed, Shaghil, 2009, "Are Chinese Exports Sensitive to Changes in the Exchange Rate?" International Finance Discussion Paper No. 987 (Washington, D.C.: Federal Reserve Board, December).

Aziz, Jahangir and Xiangming Li, 2008, "China's Changing Trade Elasticities," China and the World Economy 16(3): 1 - 21.

Baltagi, Badi Hani, 2002, "Econometrics," Springer Science \& Business Media, Jan 1.

Bems, Rudolfs and Robert C. Johnson, 2012, "Value-Added Exchange Rates," NBER Working Paper, 18498.

Cheung, Yin-Wong and Kon S. Lai, 1995. "Lag Order and Critical Values of a Modified DickeyFuller Test," Oxford Bulletin of Economics and Statistics, Department of Economics, University of Oxford, vol. 57(3), pages 411-19.

Cheung, Yin-Wong, Menzie D. Chinn and Eiji Fujii, 2007, “The Overvaluation of Renminbi Undervaluation," Journal of International Money and Finance, 26(5) : 762-85.

Cheung, Yin-Wong, Menzie D. Chinn and Eiji Fujii, 2009, "Pitfalls in Measuring Exchange Rate Misalignment: The Yuan and Other Currencies," Open Economies Review 20: 183-206.

Cheung, Yin-Wong, Menzie D. Chinn and Eiji Fujii, 2010a, "China's Current Account and Exchange Rate," Chapter 9, pp. 231-271, China's Growing Role in World Trade, edited by Robert Feenstra and Shing-Jin Wei, University of Chicago Press for NBER.

Cheung, Yin-Wong, Menzie D. Chinn and Eiji Fujii, 2010b, "Measuring Renminbi Misalignment: Where Do We Stand?" Korea and the World Economy 11: 263-296.

Cheung, Yin-Wong, Menzie D. Chinn and XingWang Qian, 2012, “Are Chinese Trade Flows Different?” Journal of International Money and Finance 31, 2127-2146.

Chinn, Menzie D., 2008, "Non-linearities, Business Cycles and Exchange Rates," Economic Notes, 37: 219-239

Chinn, Menzie D., 2006, "A Primer on Real Effective Exchange Rates: Determinants, Overvaluation, Trade Flows and Competitive Devaluations," Open Economies Review 17(1) (January): 115-143.

Coudert, Virginie and Cecile Couharde, 2007, "Real Equilibrium Exchange Rate in China: Is the Renminbi Undervalued?” Journal of Asian Economics 18 (4): 568-594.

Dekle, Robert and Murat Ungor, 2013, "The Real Exchange Rate and the Structural Transformation(s) of China and the U.S." International Economic Journal, Vol. 27, Iss. 2 pages 303-319

Eichengreen, Barry, Yeongseop Rhee and Hui Tong, 2007, "China and the Exports of Other Asian Countries," Review of World Economics, 143, 2, 201-26.

Frankel, Jeffrey A., 2006, "On the Yuan: The Choice Between Adjustment Under a Fixed Exchange Rate and Adjustment under a Flexible Rate," in Gerhard Illing, ed., Understanding the Chinese Economy, CESifo Economic Studies, 52(2), Oxford University Press: 246-75. Also NBER Working Paper No.11274, Cambridge MA: National Bureau of Economic Research.

Fratzscher, Marcel, and Arnaud Mehl, 2014, "China's Dominance Hypothesis and the Emergence of a Tri-polar Global Currency System." The Economic Journal.

Garcia-Herrero, Alicia and Tuuli Koivu, 2007, "Can the Chinese Trade Surplus Be Reduced through Exchange Rate Policy?” BOFIT Discussion Papers No. 2007-6 (Helsinki: Bank of Finland, March). 
Gaulier, Guillaume, Françoise Lemoine and Deniz Ünal, 2006, “China’s Emergence and the Reorganization of Trade Flows in Asia," CEPII Working Paper No.2006-05, Paris: CEPII, March.

Kwack, Sung Yeung, Choong Y. Ahn, Young S. Lee and Doo Y. Yang, 2007, “Consistent Estimates of World Trade Elasticities and an Application to the Effects of Chinese Yuan (RMB) Appreciation," Journal of Asian Economics, 18: 314-30.

Mann, Catherine and Katerina Plück, 2007, "The US Trade Deficit: A Disaggregated Perspective," in R. Clarida (ed.), G7 Current Account Imbalances: Sustainability and Adjustment (U. Chicago Press). Also Institute for International Economics Working No. 05-11, (Washington, D.C.: Institute for International Economics, 2005).

Marquez, Jaime and John W. Schindler, 2007, "Exchange-Rate Effects on China's Trade," Review of International Economics 15(5), 837-853.

McKinnon, Ronald and Gunther Schnabl, 2003, "Synchronized Business Cycles in East Asia and Fluctuations in the Yen/Dollar Exchange Rate," The World Economy, Volume 26, Issue 8, pages $1067-1088$.

Pagan, Adrian, 1984, "Econometric Issues in the Analysis of Regressions with Generated Regressors," International Economic Review, Vol. 25, No. 1 (Feb., 1984), pp. 221-247

Perron, Pierre and Timothy J. Vogelsang, 1992, "Nonstationarity and Level Shifts with an Application to Purchasing Power Parity," Journal of Business and Economic Statistics, 10, pp. 301-320.

Pesaran, Hashem, Yongcheol Shin and Richard Smith, 2001, "Bounds testing approaches to the analysis of level relationships," Journal of Applied Econometrics 16, 289-326.

Subramanian, Arvind and Martin Kessler, 2013, "The Renminbi Bloc is Here: Asia Down, Rest of the World to Go?" PIIE Working Paper 12 - 19, Washington D.C.

Thorbecke, Willem and Gordon Smith, 2010, "How Would an Appreciation of the RMB and Other East Asian Currencies Affect China's Exports?" Review of International Economics. 18 (1): 95-108.

Thorbecke, Willem, 2006, "How Would an Appreciation of the Renminbi Affect the US Trade Deficit with China?" BE Press Macro Journal 6(3): Article 3.

Thorbecke, Willem, 2013, "Updated Estimates of the People's Republic of China's Export Elasticities: Using Panel Data and Integrated Exchange Rates," manuscript, Research Institute of Economy, Trade and Industry.

Thorbecke, Willem, 2014, "China-US Trade: A Global Outlier" manuscript, Research Institute of Economy, Trade and Industry.

Wang, Tao, 2004, "Exchange Rate Dynamics," in Eswar Prasad, ed., China's Growth and Integration into the World Economy, Occasional Paper No.232, Washington, D.C.: International Monetary Fund: 21-8. 
Table 1: China's Aggregate Exports to US (1994Q1-2012Q4)

\begin{tabular}{|c|c|c|c|}
\hline & \multicolumn{3}{|c|}{ Aggregate exports } \\
\hline & (1) & (2) & (3) \\
\hline \multirow[t]{2}{*}{ GDP_US } & $3.041 * * *$ & $3.041 * * *$ & $3.944 * * *$ \\
\hline & $(0.86)$ & $(1.21)$ & $(0.82)$ \\
\hline \multirow[t]{2}{*}{ RER } & $-1.687 * * *$ & $-0.999 * * *$ & $-2.348 * * *$ \\
\hline & $(0.33)$ & $(0.26)$ & $(0.33)$ \\
\hline \multirow[t]{2}{*}{ REER_US/ASEAN } & 0.216 & -0.007 & -0.033 \\
\hline & $(0.17)$ & $(0.22)$ & $(0.25)$ \\
\hline \multirow[t]{2}{*}{$d$ Proc_Imports } & $0.440^{* *}$ & $0.658^{*}$ & 0.184 \\
\hline & $(0.21)$ & $(0.35)$ & $(0.15)$ \\
\hline F-stats & 11.08 & 4.85 & 10.14 \\
\hline t-stats & -6.96 & -6.16 & -6.29 \\
\hline Q-stat(4) & 7.96 & 6.38 & 7.01 \\
\hline Q-stat(8) & 12.08 & 9.58 & 12.04 \\
\hline Jarque-Bera test & 2.27 & .55 & .92 \\
\hline Obs & 68 & 68 & 68 \\
\hline Lag & $(1,2,1,3)$ & $(1,4,1,3)$ & $(1,3,4,1)$ \\
\hline
\end{tabular}

Note: Column (1), Column (2), and Column (3) report results when the RER variable is the CPI based RER, the one from the twostage estimation method, and the deviation from the equilibrium levels. Robust standard errors are in the parentheses. "***, **, *" indicate the $1 \%, 5 \%$, and $10 \%$ level of significance, respectively. The estimation results for short-term variables, WTO, exchange rate reform dummy, Crisis dummy, quarterly dummies, and constant are not reported for brevity. F-stats and t-stats report the test results for null hypotheses of $\beta_{1}=\beta_{2}=\beta_{3}=\beta_{4}=\beta_{5}=0$ and $\beta_{1}=0$. Q-stat and Jarque-Bera test report the test results of serial correlation and normality of the regression error term, respectively. The lag structure is decided by the SBIC. For example, $(1,2,1,3)$ means the first differences of GDP_US, RER, REER_US/ASEAN, and dProc_Imports have 1, 2, 1, and 3 lag(s) in the Bounds test procedure, respectively. 
Table 2: China Exports to US - Ordinary and Processing exports (2001Q1-2012Q4)

\begin{tabular}{|c|c|c|c|c|c|c|}
\hline & \multicolumn{3}{|c|}{ Ordinary exports } & \multicolumn{3}{|c|}{ Processing exports } \\
\hline & (1) & (2) & (3) & (4) & (5) & (6) \\
\hline \multirow[t]{2}{*}{ GDP_US } & $3.480 * * *$ & 1.272 & $3.811 * *$ & 0.529 & 1.181 & 1.278 \\
\hline & $(1.25)$ & $(3.25)$ & $(1.37)$ & $(1.77)$ & $(1.72)$ & (1.90) \\
\hline \multirow[t]{2}{*}{ RER } & $-2.199 * * *$ & $-1.598 *$ & $-1.817 * * *$ & $-1.873 * * *$ & $-0.930 * * *$ & $-2.446 * * *$ \\
\hline & $(0.59)$ & $(0.88)$ & $(0.55)$ & $(0.42)$ & $(0.31)$ & $(0.49)$ \\
\hline \multirow[t]{2}{*}{ REER_US/ASEAN } & $-1.060 *$ & $-0.621 * *$ & -0.361 & 1.026 & 0.423 & 0.450 \\
\hline & $(0.61)$ & $(0.27)$ & $(0.51)$ & $(0.71)$ & $(0.79)$ & $(0.49)$ \\
\hline \multirow[t]{2}{*}{$d$ Proc_Imports } & & & & 0.198 & $1.176^{* * *}$ & 0.511 \\
\hline & & & & $(0.18)$ & $(0.29)$ & $(0.35)$ \\
\hline F-stats & 7.91 & 4.27 & 7.11 & 5.96 & 6.32 & 4.97 \\
\hline t-stats & -4.76 & -4.39 & -4.69 & -3.55 & -3.93 & -4.28 \\
\hline Q-stat(4) & 3.73 & 7.34 & 4.05 & 6.64 & 6.95 & 7.29 \\
\hline Q-stat(8) & 8.23 & 12.23 & 10.25 & 13.27 & 9.04 & 12.70 \\
\hline Jarque-Bera test & .38 & .45 & .35 & 1.25 & 1.79 & .84 \\
\hline Obs & 46 & 43 & 46 & 43 & 43 & 43 \\
\hline Lag & $(1,1,4)$ & $(2,4,2)$ & $(1,1,4)$ & $(1,2,1,1)$ & $(1,1,1,4)$ & $(1,3,2,1)$ \\
\hline
\end{tabular}

Note: Columns (1) and (4), Columns (2) and (5), and Columns (3) and (6) report results when the RER variable is the CPI based RER, the one from the two-stage estimation method, and the deviation from the equilibrium levels. Robust standard errors are in the parentheses. "***, $* *, *$ " indicate the $1 \%, 5 \%$, and $10 \%$ level of significance, respectively. The estimation results for short-term variables, WTO, exchange rate reform dummy, Crisis dummy, quarterly dummies, and constant are not reported for brevity. F-stats and $t$-stats report the test results for null hypotheses of $\beta_{1}=\beta_{2}=\beta_{3}=\beta_{4}=\beta_{5}=0$ and $\beta_{1}=0$. Q-stat and Jarque-Bera test report the test results of serial correlation and normality of the regression error term, respectively. The lag structure is decided by the SBIC. For example, $(1,2,1,1)$ means the first differences GDP_US, RER, REER_US/ASEAN, and dProc_Imports have 1, 2, 1, and 1 lag in the Bounds test procedure, respectively. 
Table 3: China Exports to US - Primary and Manufactured product exports (1994Q1-2012Q4)

\begin{tabular}{|c|c|c|c|c|c|c|}
\hline & \multicolumn{3}{|c|}{ Primary exports } & \multicolumn{3}{|c|}{ Manufactured exports } \\
\hline & (1) & (2) & (3) & (4) & $(5)$ & (6) \\
\hline GDP_US & $3.135^{*}$ & $4.809 * *$ & 2.230 & $2.636^{* * *}$ & 1.226 & $3.422 * * *$ \\
\hline & $(1.83)$ & $(1.99)$ & $(1.41)$ & $(0.84)$ & $(1.05)$ & $(0.82)$ \\
\hline RER & $\begin{array}{c}-1.853^{* * *} \\
(0.42)\end{array}$ & $\begin{array}{l}-0.092 \\
(0.14)\end{array}$ & $\begin{array}{c}-2.546^{* * *} \\
(0.55)\end{array}$ & $\begin{array}{c}-1.744 * * * \\
(0.32)\end{array}$ & $\begin{array}{c}-0.868^{* * *} \\
(0.29)\end{array}$ & $\begin{array}{c}-1.790 * * * \\
(0.38)\end{array}$ \\
\hline REER_US/ASEAN & $\begin{array}{c}-0.540^{* *} \\
(0.23)\end{array}$ & $\begin{array}{c}-0.385^{*} \\
(0.22)\end{array}$ & $\begin{array}{c}-0.798^{* *} \\
(0.31)\end{array}$ & $\begin{array}{l}0.153 \\
(0.16)\end{array}$ & $\begin{array}{l}0.182 \\
(0.21)\end{array}$ & $\begin{array}{l}0.161 \\
(0.16)\end{array}$ \\
\hline$d$ Proc_Imports & & & & $\begin{array}{c}0.454^{* *} \\
(0.20)\end{array}$ & $\begin{array}{c}1.589 * * * \\
(0.28)\end{array}$ & $\begin{array}{c}0.437 * * \\
(0.22)\end{array}$ \\
\hline F-stats & 10.12 & 8.44 & 7.68 & 9.95 & 8.45 & 6.06 \\
\hline t-stats & -6.30 & -4.85 & -5.44 & -6.84 & -6.28 & -5.62 \\
\hline Q-stat(4) & 7.58 & 0.66 & 5.75 & 7.12 & 8.00 & 7.46 \\
\hline Q-stat(8) & 13.23 & 5.09 & 13.28 & 10.33 & 12.72 & 11.74 \\
\hline Jarque-Bera test & .59 & 1.24 & 1.20 & 2.12 & 2.21 & 2.28 \\
\hline Obs & 71 & 72 & 71 & 68 & 68 & 68 \\
\hline Lag & $(4,2,3)$ & $(1,3,3)$ & $(2,2,4)$ & $(1,2,1,3)$ & $(1,3,1,3)$ & $(1,4,1,3)$ \\
\hline
\end{tabular}

Note: Columns (1) and (4), Columns (2) and (5), and Columns (3) and (6) report results when the RER variable is the CPI based RER, the one from the two-stage estimation method, and the deviation from the equilibrium levels. Robust standard errors are in the parentheses. " $* * *, * *, *$ indicate the $1 \%, 5 \%$, and $10 \%$ level of significance, respectively. The estimation results for short-term variables, WTO, exchange rate reform dummy, Crisis dummy, quarterly dummies, and constant are not reported for brevity. F-stats and $t$-stats report the test results for null hypotheses of $\beta_{1}=\beta_{2}=\beta_{3}=\beta_{4}=\beta_{5}=0$ and $\beta_{1}=0$. Q-stat and Jarque-Bera test report the test results of serial correlation and normality of the regression error term, respectively. The lag structure is decided by the SBIC. For example, $(1,2,1,3)$ means the first differences GDP_US, RER, REER_US/ASEAN, and dProc_Imports have 1, 2, 1, and 3 lag in the Bounds test procedure, respectively. 
Table 4: China Exports to US - SOE, FIE, Priv. exports (2001Q1-2012Q4)

\begin{tabular}{|c|c|c|c|c|c|c|c|c|c|}
\hline & \multicolumn{3}{|c|}{ SOE exports } & \multicolumn{3}{|c|}{ FIE exports } & \multicolumn{3}{|c|}{ Priv. exports } \\
\hline & (1) & (2) & (3) & (4) & (5) & (6) & (7) & (8) & (9) \\
\hline \multirow[t]{2}{*}{ GDP_US } & $3.434 * * *$ & $3.848 * *$ & $3.495 * *$ & 0.881 & 0.604 & 1.014 & 2.096 & $4.997 * *$ & 0.549 \\
\hline & $(1.05)$ & $(1.69)$ & $(1.73)$ & $(1.66)$ & $(2.12)$ & $(1.54)$ & $(1.66)$ & $(2.11)$ & $(2.45)$ \\
\hline \multirow[t]{2}{*}{ RER } & -0.186 & $-0.697 *$ & -0.594 & $-1.798 * * *$ & $-1.283 * * *$ & $-2.381 * * *$ & $-2.187 * * *$ & $-2.294 * * *$ & $-2.520 * * *$ \\
\hline & $(0.43)$ & $(0.40)$ & $(0.42)$ & $(0.40)$ & $(0.39)$ & $(0.37)$ & $(0.78)$ & $(0.72)$ & $(0.56)$ \\
\hline REER_US/ASEAN & -0.519 & -0.812 & -0.212 & 0.819 & -0.256 & 0.668 & $-2.072 *$ & $1.246 * * *$ & -0.451 \\
\hline \multirow[t]{2}{*}{$d$ Proc_Imports } & $1.412 * * *$ & $1.836^{* * *}$ & $1.498 * * *$ & $0.828 * * *$ & $1.569 * * *$ & $0.627 * *$ & 0.011 & $1.971 * * *$ & -0.772 \\
\hline & $(0.36)$ & $(0.53)$ & $(0.59)$ & $(0.32)$ & $(0.39)$ & $(0.31)$ & $(0.21)$ & $(0.53)$ & $(0.56)$ \\
\hline F-stats & 20.89 & 13.53 & 8.23 & 7.70 & 7.46 & 6.28 & 4.52 & 6.20 & 4.80 \\
\hline t-stats & -5.90 & -4.10 & -4.15 & -4.69 & -3.55 & -4.34 & -3.83 & -4.16 & -3.68 \\
\hline Q-stat(4) & 6.75 & 7.35 & 6.77 & 6.62 & 7.73 & 5.39 & 3.93 & 3.98 & 6.61 \\
\hline Q-stat(8) & 12.78 & 11.85 & 11.19 & 7.56 & 10.55 & 11.76 & 7.06 & 4.30 & 9.70 \\
\hline Obs & 43 & 42 & 43 & 43 & 43 & 43 & 43 & 42 & 43 \\
\hline Lag & $(1,3,1,4)$ & $(1,2,2,4)$ & $(2,1,1,4)$ & $(1,1,1,4)$ & $(1,1,1,4)$ & $(1,2,1,4)$ & $(1,4,3,1)$ & $(4,2,2,4)$ & $(4,4,2,4)$ \\
\hline
\end{tabular}

Note: Columns (1), (4) and (7), Columns (2), (5) and (8), and Columns (3), (6) and (9) report results when the RER variable is the CPI based RER, the one from the two-stage estimation method, and the deviation from the equilibrium levels. Robust standard errors are in the parentheses. "***,**,*" indicate the $1 \%, 5 \%$, and $10 \%$ level of significance, respectively. The estimation results for short-term variables, WTO, exchange rate reform dummy, Crisis dummy, quarterly dummies, and constant are not reported for brevity. F-stats and $t$-stats report the test results for null hypotheses of $\beta_{1}=\beta_{2}=\beta_{3}=\beta_{4}=\beta_{5}=0$ and $\beta_{1}=0$. Q-stat and Jarque-Bera test report the test results of serial correlation and normality of the regression error term, respectively. The lag structure is decided by the SBIC. For example, $(1,3,1,4)$ means the first differences GDP_US, RER, REER_US/ASEAN, and dProc_Imports have 1, 3, 1, and 4 lag in the Bounds test procedure, respectively. 
Table 5: China Imports from US - Two-stage method

\begin{tabular}{|c|c|c|c|c|c|c|c|c|}
\hline \multirow{3}{*}{ GDP_CN } & Aggregate & Ordinary & Processing & Primary & Manufactured & SOE & FIE & Priv. \\
\hline & -0.639 & 0.466 & 2.956 & -0.618 & -2.414 & -2.863 & 0.502 & $4.684 * * *$ \\
\hline & $(0.69)$ & $(4.47)$ & $(6.36)$ & $(1.72)$ & $(2.51)$ & $(2.11)$ & $(1.83)$ & (1.69) \\
\hline \multirow[t]{2}{*}{ RER } & $0.362 * * *$ & $1.685^{*}$ & $5.012 * * *$ & $0.393 * * *$ & 0.211 & $0.671 *$ & $0.378 * * *$ & 0.040 \\
\hline & $(0.06)$ & $(0.90)$ & $(1.27)$ & $(0.07)$ & $(0.29)$ & $(0.38)$ & $(0.13)$ & $(0.38)$ \\
\hline \multirow{2}{*}{ REER_CN/EU } & 0.010 & $-2.278^{* * *}$ & $-4.532 * * *$ & -0.087 & 0.056 & -0.660 & $2.100 * * *$ & 0.558 \\
\hline & $(0.21)$ & $(0.62)$ & (1.03) & $(0.49)$ & $(0.30)$ & $(0.49)$ & $(0.51)$ & $(0.36)$ \\
\hline \multirow[t]{2}{*}{$d$ Prod } & 0.204 & $-1.718^{* * *}$ & $-17.999 * * *$ & -1.071 & 0.683 & $-2.416^{* * *}$ & $-1.286^{* *}$ & $1.206^{* *}$ \\
\hline & $(0.32)$ & $(0.60)$ & (3.11) & (1.07) & $(0.48)$ & $(0.82)$ & $(0.59)$ & $(0.55)$ \\
\hline F-stats & 11.31 & 5.03 & 8.87 & 7.50 & 7.90 & 8.19 & 11.25 & 10.79 \\
\hline t-stats & -6.86 & -4.43 & -4.96 & -7.28 & -6.10 & -6.28 & -6.47 & -7.80 \\
\hline Q-stat(4) & 1.58 & 3.33 & 7.58 & 4.94 & 2.40 & 5.95 & 3.10 & 4.55 \\
\hline Q-stat(8) & 8.23 & 4.34 & 11.95 & 11.02 & 11.79 & 12.70 & 6.97 & 9.18 \\
\hline Jarque-Bera test & .49 & 3.71 & .15 & 3.86 & .76 & .75 & .82 & .54 \\
\hline Obs & 71 & 43 & 44 & 71 & 72 & 44 & 43 & 43 \\
\hline Lag & $(1,3,1,2)$ & $(4,4,4,3)$ & $(1,3,2,3)$ & $(1,3,1,3)$ & $(2,1,1,2)$ & $(2,1,4,3)$ & $(2,4,3,1)$ & $(1,1,2,1)$ \\
\hline \multicolumn{9}{|c|}{$\begin{array}{l}\text { Note: The table reports China's imports elasticities with the RER variable from the two-stage estimation method. Robust standard } \\
\text { errors are in the parentheses. "***,**, * indicate the } 1 \%, 5 \% \text {, and } 10 \% \text { level of significance, respectively. The estimation results for } \\
\text { short-term variables, WTO, exchange rate reform dummy, Crisis dummy, quarterly dummies, and constant are not reported for brevity } \\
\text { F-stats and t-stats report the test results for null hypotheses of } \beta_{1}=\beta_{2}=\beta_{3}=\beta_{4}=\beta_{5}=0 \text { and } \beta_{1}=0 \text {. Q-stat and Jarque-Bera test report } \\
\text { the test results of serial correlation and normality of the regression error term, respectively. The lag structure is decided by the SBIC. } \\
\text { For example, }(1,3,1,2) \text { means the first differences GDP_CN, RER, REER_CN/EU, and dProd have } 1,3,1 \text {, and } 2 \text { lag in the Bounds test } \\
\text { procedure, respectively. }\end{array}$} \\
\hline
\end{tabular}


Table 6: The summary of price elasticity of trade and Marshall-Lerner condition

\begin{tabular}{|c|c|c|c|c|}
\hline Data type of trade & Price elasticity of exports $\left(\Psi_{\mathrm{ex}}\right)$ & Price elasticity of imports ( $\left.\Psi_{\mathrm{im}}\right)$ & $\begin{array}{l}\text { Marshall-Lerner Condition } \\
\left(\Psi_{\mathrm{ex}}+\Psi_{\mathrm{im}}\right)\end{array}$ & Chi Statistics \\
\hline Aggregate & 0.999 & 0.362 & 1.362 & $3.21 *$ \\
\hline Ordinary & 3.863 & 1.685 & 5.548 & $8.37 * * *$ \\
\hline Processing & 0.93 & 5.012 & 5.942 & $5.59 * *$ \\
\hline Primary & 0.108 & 0.393 & 0.501 & 0.09 \\
\hline Manufactured & 0.868 & 0.211 & 1.079 & 1.08 \\
\hline SOE & 0.697 & 0.671 & 1.368 & 0.72 \\
\hline FIE & 1.283 & 0.378 & 1.661 & $3.36^{*}$ \\
\hline Priv. & 2.294 & 0.04 & 2.334 & $3.57 * *$ \\
\hline
\end{tabular}




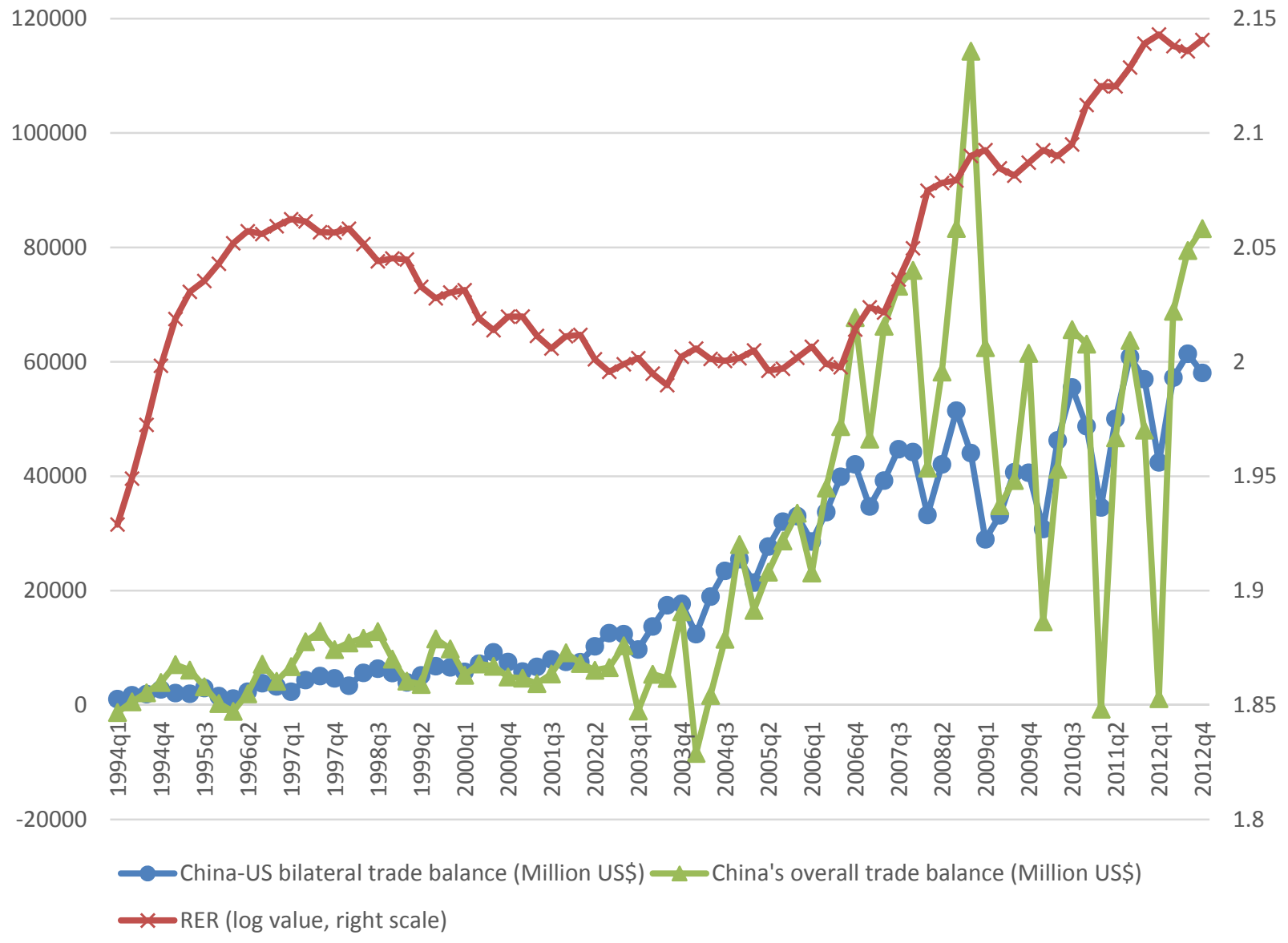

Figure 1: China's overall, China-US bilateral trade balance, and the RMB real exchange rate 


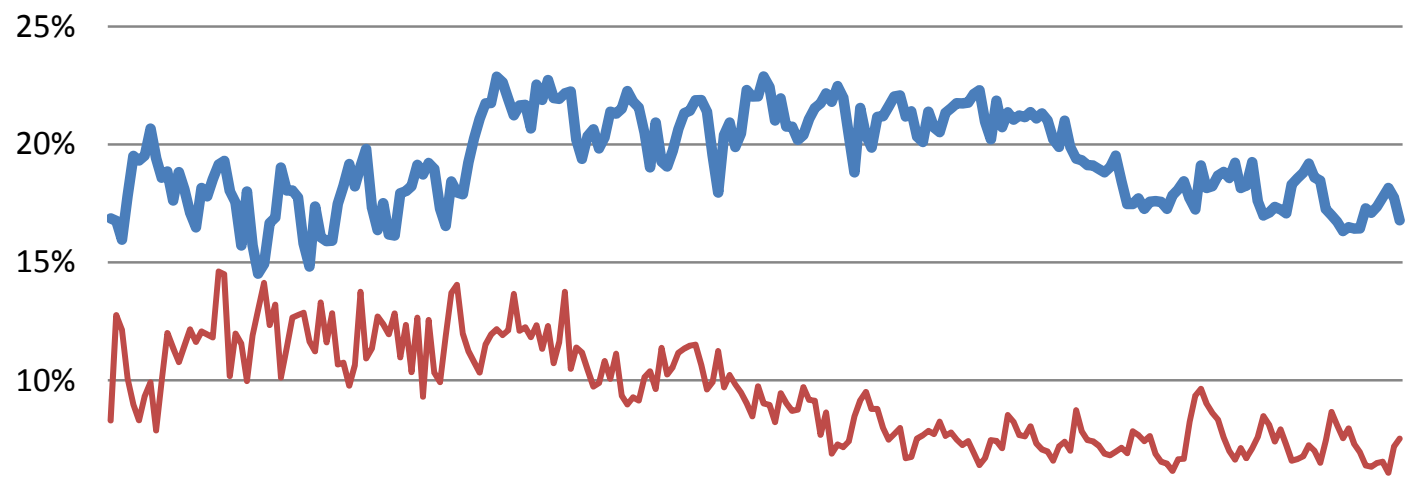

$5 \%$

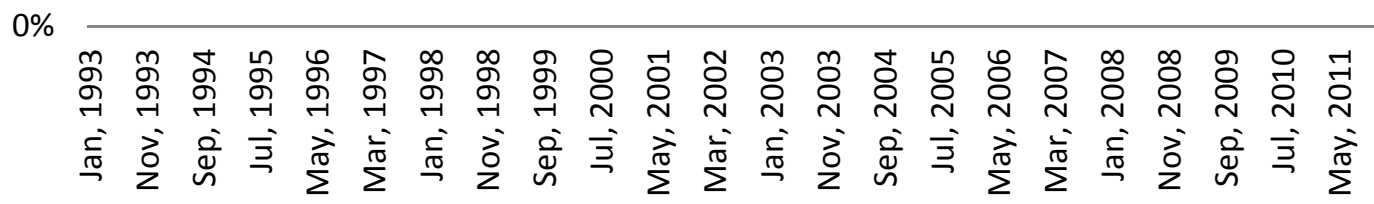

the share of Chinese exports to the US in Chinese total exports

— the share of Chinese imports from the US in Chinese total imports

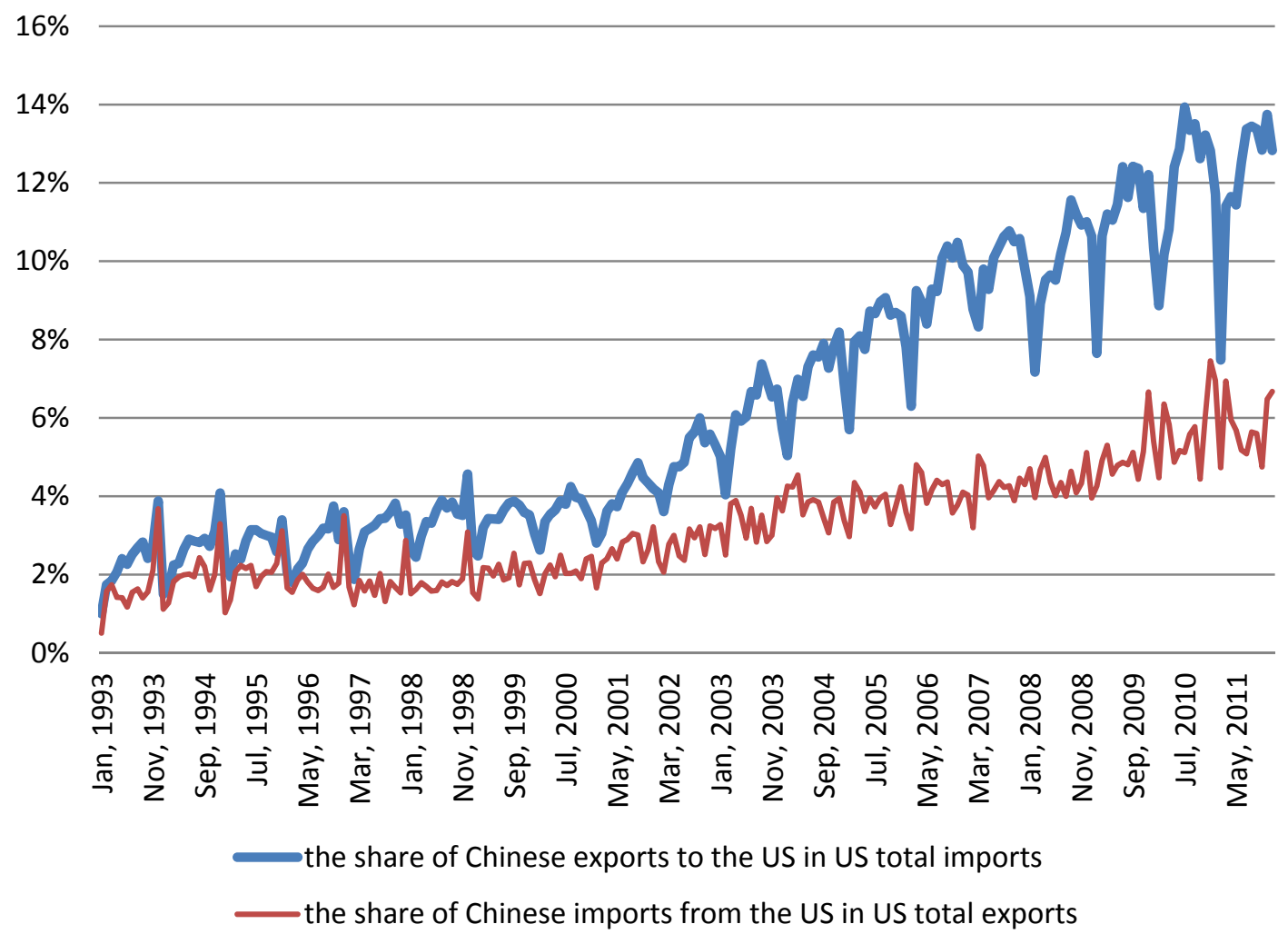

Figure 2: The shares of China-US bilateral trade 


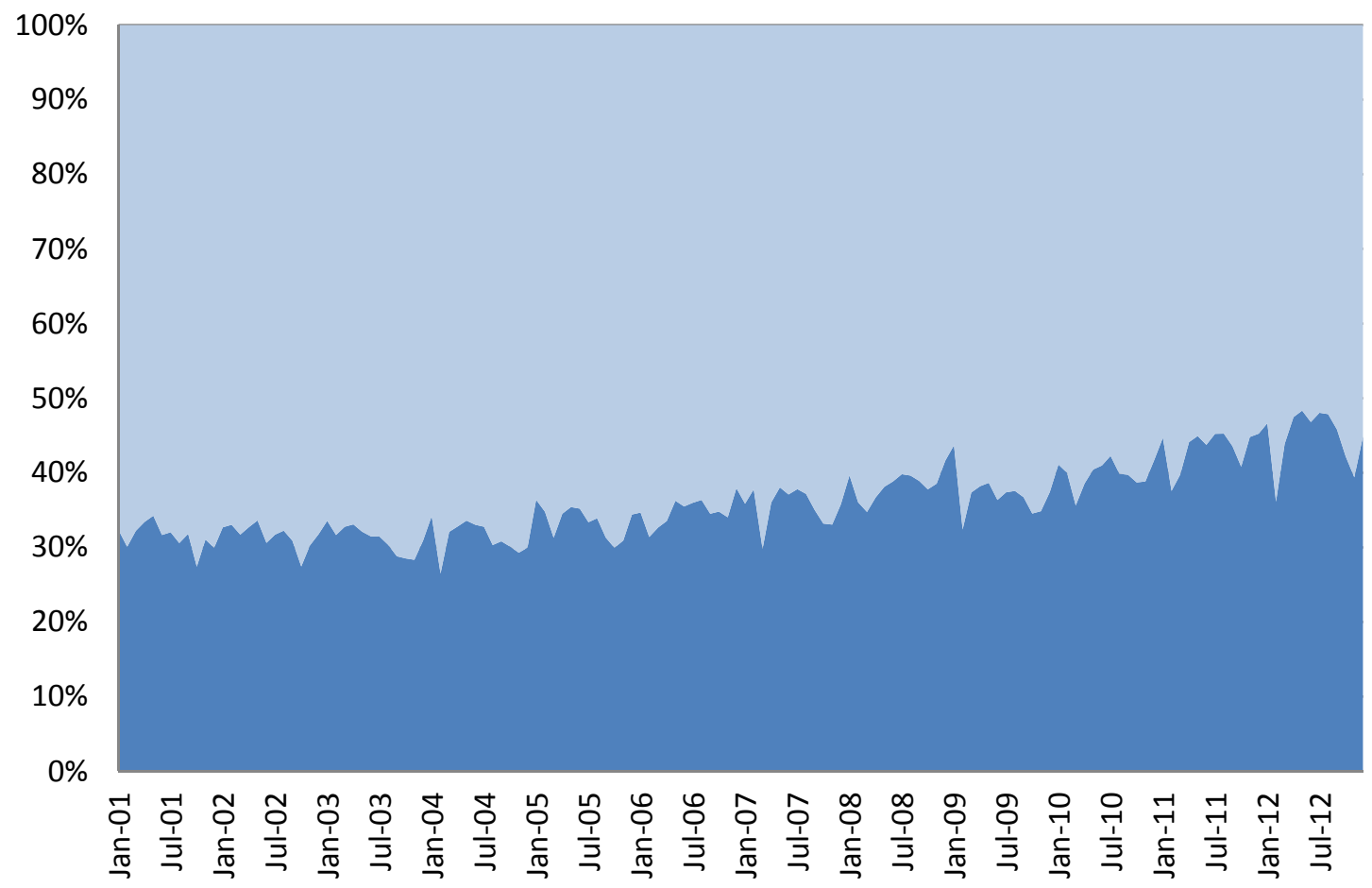

Exports: Ordinary Trade $\quad$ Exports: Processing Trade

Figure 3: China's ordinary and processing exports to the U.S.

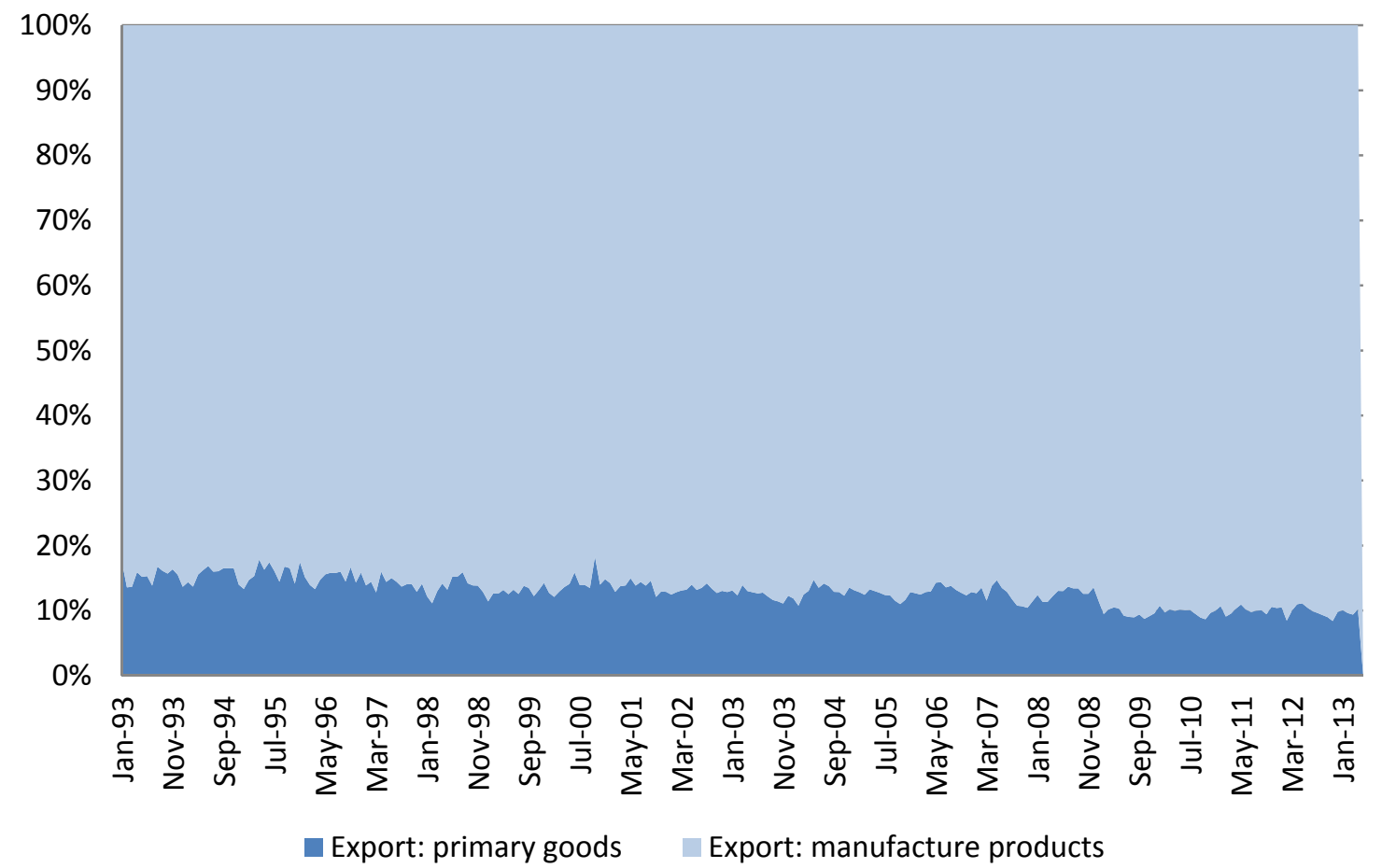

Figure 4: China's primary and manufactured exports to the U.S. 


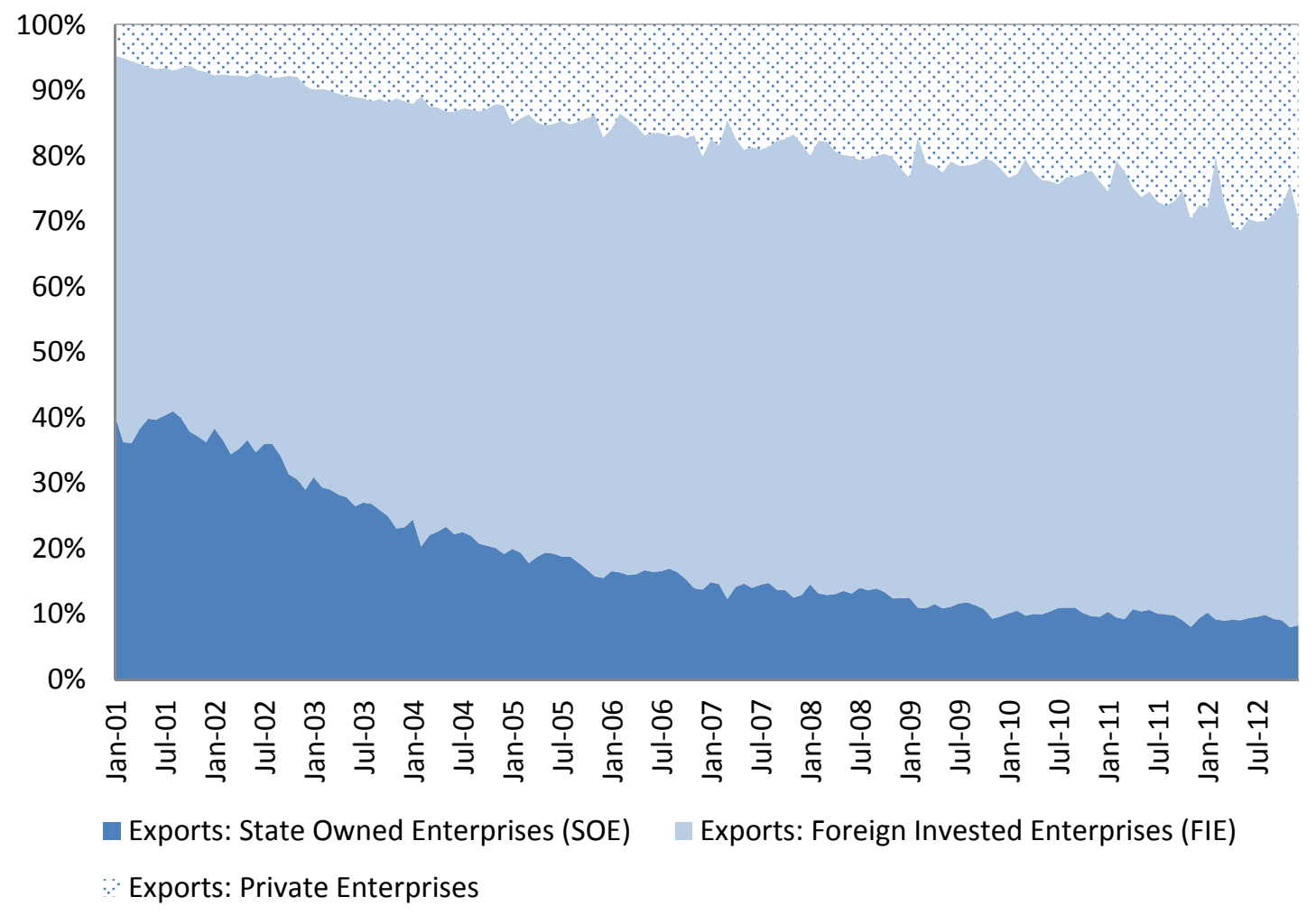

Figure 5: Exports of different types of firm to the US 